\title{
РУССКИЕ В РЕСПУБЛИКАХ СЕВЕРНОГО КАВКАЗА - РУБЕЖИ ГЕОДЕМОГРАФИЧЕСКОГО ОТСТУПЛЕНИЯ (ПЕРВАЯ ПОЛОВИНА ХХІ ВЕКА)
}

\section{СЕРГЕЙ СУЩИЙ}

\begin{abstract}
В статье анализируется геодемографическая динамика русского населения республик Северного Кавказа в постсоветский период. Фиксируются темпы его сокращения по республикам, исследуется изменчивое соотношение в данном процессе естественной и миграционной составляющих. Выявлена центральная роль оттока в сокращении численности русского населения региона, которая в настоящее время опустилась до уровня серединь 1930-х годов. При этом произошло практически полное вытеснение русских из Чеченской Республики и Ингушетии, значительную часть своего русского населения утратил Дагестан. В результате общее число русских на Северо-Восточном Кавказе в постсоветский период сократилась почти в 4 раза. Демографические потери русского населения остальных республик региона были не столь значительны. Однако ускоренное сокращение числа русских и в них стало устойчивой тенденџией. Для определения коридора наиболее вероятной динамики численности русского населения региона (и отдельных его республик) на среднесрочную и более удаленную (до 2050 г.) перспективу были сделаны расчеты, исходя из различных вариантов естественного прироста и миграционной активности русского населения. Установлено, что к 2030 г. число русских на Северном Кавказе сократится до 690-780 тыс. человек, а к середине века будет находиться в диапазоне 490-700 тыс.

Наряду с прямым количественным сокращением будет происходить ухудшение возрастной структуры русского населения региона, способное привести кего демографическому «коллапсу» уже в 2060-2070-е годы.
\end{abstract}

Ключевые слова: Северный Кавказ, русское население, демографическая динамика, расселение, миграчия, ассимиляционные прочессы.

\section{НОВЫЕ ЧЕРТЫ МИГРАЦИОННОЙ ПОЛИТИКИ}

Русские, составляющие более $80 \%$ населения страны, являются наиболее многочисленным народом Российского государства. Поэтому неудивительно и их традиционное присутствие во всех макрорегионах страны, равно как и их активное участие в социальной жизнедеятельности этих макрорегионов. Соответственно значимым показателем служит и социодемографическая динамика русского населения в регионах РФ, в том числе и в национальных автономиях. Динамика численности (и удельного веса) местного русского населения, направления его миграции и масштабы оттока - значимые характеристики уровня интеграции республик в жизнедеятельные циклы всей России.

СЕРГЕЙ ЯКОВЛЕВИЧ СУЩИЙ (SS7707@mail.ru), ИНСТИТУТ СОЦИАЛЬНО-ЭКОНОМИЧЕСКИХ И ГУМАНИТАРНЫХ ИССЛЕДОВАНИЙ ЮНЦ РАН, РОССИЯ.

РАБОТА ВЫПОЛНЕНА В РАМКАХ ПРОЕКТА «ПРОБЛЕМЫ ДЕМОГРАФИЧЕСКОГО И СОЦИАЛЬНО-ЭКОНОМИЧЕСКОГО РАЗВИТИЯ ЮЖНОГО МАКРОРЕГИОНА (О260-2014-0004)» ПРОГРАММЫ ФУНДАМЕНТАЛЬНЫХ ИССЛЕДОВАНИЙ ПРЕЗИДИУМА РАН.

СТАТЬЯ ПОСТУПИЛА В РЕДАКЦИЮ В АПРЕЛЕ 2017 Г. 
Потому быстрое сокращение русского населения Северного Кавказа в постсоветский период вполне обоснованно воспринимается экспертами и российским обществом в целом как настораживающий признак. Количество исследований, посвященных различным аспектам данной темы, достаточно велико [Атаев 2013; Белозеров 2001; Денисова, Уланов 2003; Дзадзиев 2007; 2008; Кабузан 1996; Северный Кавказ... 2010]. Однако детальный анализ современной количественной динамики русского населения Северного Кавказа, а также его геодемографических перспектив пока не привлек достаточного внимания специалистов.

Отток русских из региона - процесс, начавшийся задолго до распада СССР. Уже в 1960-х годах была зафиксирована миграция русского населения из Дагестана (таблица 1). Однако в целом по региону миграционное сальдо русских всё еще оставалось положительным. Но уже в следующем десятилетии ситуация меняется кардинально - в 1970-е годы почти весь Северный Кавказ оказывается в зоне миграционный убыли русских. Такое положение сохраняется и в 1980-е годы. Основный отток в последние два советских десятилетия формируют две восточные республики региона - Дагестан и ЧеченоИнгушетия.

Таблица 1. Миграционная динамика русского населения в республиках Северного Кавказа в 1960-2000-е годы, тыс. чел.*

\begin{tabular}{l|r|r|r|r|r}
\hline \multirow{2}{*}{ Республики } & \multicolumn{7}{c}{ Периоды } \\
\cline { 2 - 6 } & $1959-1970$ & $1970-1979$ & $1980-1989$ & $1989-2002$ & $2002-2010$ \\
\hline Адыгея & $5-7$ & $-1-2$ & 0 & $7-8$ & $-5-6$ \\
Дагестан & $-25-30$ & -30 & $-31-33$ & -35 & $-8-9$ \\
Ингушетия & - & - & - & -20 & $-1-1,5$ \\
Кабардино-Балкария & $30-35$ & $3-4$ & $-2-3$ & $-9-10$ & $-15-16$ \\
Карачаево-Черкесия & 0 & $-3-4$ & $6-7$ & -18 & $-11-12$ \\
Северная Осетия & $2-3$ & $-9-10$ & $-18-20$ & -18 & $-4-5$ \\
Чечено-Ингушетия & 0 & $-45-50$ & $-55-57$ & - & - \\
Чеченская республика & - & - & - & $-248-250$ & $-2-3$ \\
Республики в целом & $12-15$ & $-85-92$ & $-100-106$ & $-341-343$ & $-60-65$ \\
\hline
\end{tabular}

Примечание: * - Рассчитано автором на основе данных об общей динамике численности русского населения и о естественном приросте русских в республиках Северного Кавказа в соответствующие периоды.

Общие миграционные потери русского населения региона в 1970-1980-е гг. составили около 200 тыс. человек. Столь значительная убыль уже не могла быть восполнена естественным приростом. Число русских на Северном Кавказе, достигнув своего исторического максимума (первая половина 1970-х годов), начало сокращаться. За период 1970-1979 гг. оно упало с 1436 тыс. до 1412 тыс. человек.

Темпы убыли русского населения, постепенно возраставшие к концу советского периода, максимально ускоряются в 1990-е годы. В первое постсоветское десятилетие регион покинуло около 340 тыс. русских. В отдельных случаях миграция, по сути, приобретала форму этнического исхода. Трудно назвать иначе происходившее в Чеченской Республике и Ингушетии в 1991-1993 гг., когда республики покинуло около 200 тыс. человек, основную массу которых составляли русские. Свой вклад в сокращение русского населения внесла и естественная убыль, к началу XXI века составлявшая 5-6\%о в год. Как 
результат, численность русских в регионе к 2002 г. опустилась ниже миллионной планки, вернувшись тем самым на уровень рубежа 1940-х годов.

Политическая и социально-экономическая стабилизация России начала XXI в. позволила существенно сократить масштабы оттока. Однако русская миграция с территории Северного Кавказа сохраняется и в 2000-е годы. В 2002-2010 гг. русское население региона по официальным данным сократилось более, чем на 100 тыс. человек. Учитывая, что размеры естественной убыли русских за этот период составляли порядка $4 \%$ (около 40 тыс. человек), остальные 60 тыс. человек демографической убыли пришлись на миграцию, интенсивность которой в ряде республик даже возросла.

В общей сложности с 1989 по 2010 г. массив русского населения Северного Кавказа сжался более чем в 1,5 раза. Еще ощутимее были удельные потери: доля русских в населении региона, достигавшая на рубеже 1960-х годов 44\%, к концу советского периода сократилась до $27 \%$, а в 2010 г. составляла уже только $12 \%$.

Причины демографического «схлопывания» республиканских русских общин хорошо известны. Они многократно озвучивались в экспертной литературе. Это экономический фактор - деиндустриализация Северного Кавказа и потеря русским населением своих основных производственных ниш; комплексная этнизация социальной жизни республик -значительное доминирование титульных народов в структурах власти и во всех престижных иерархиях; правовая незащищенность русского населения и существующая в республиках межэтническая напряженность.

Очевидно и то, что «русский вопрос» не является самостоятельным, но представляет один из составных элементов широкого проблемного комплекса, решение которого возможно только в результате успешной реализации проекта системной трансформации Северного Кавказа - серьезной модернизации его политической, социальноэкономической, культурной жизни, которая в свою очередь предполагает соответствующие изменения социальных реалий всей России. Однако современная российская власть такого масштаба задачи предпочитает перед собой не ставить. Потому есть все основания полагать, что геодемографическая динамика русского населения на Северном Кавказе будет по-прежнему определяться факторами, способствующими его дальнейшему количественному сокращению и пространственному сжатию.

Этот процесс, представляющий сложную производную этнополитических, социально-экономических и социокультурных факторов, задающих масштабы оттока русских, будет существенно различаться по республикам. Однако варьировать в достаточно широком диапазоне может не только миграция, но и показатели естественной динамики русских. Соотношение рождаемости и смертности будет зависеть как от социальноэкономической успешности всей РФ и конкретного региона, так и особенностей демографической политики российской власти, масштаба программ поощрения рождаемости, уровня развития системы здравоохранения, широты распространения здорового образа жизни, эффективности борьбы государства (и самого общества) с алкоголизмом, курением и наркоманией. 
В настоящей статье содержится попытка оценить возможные изменения численности русского населения республик Северного Кавказа с использованием метода передвижки возрастов при разных вариантах изменения параметров естественного воспроизводства русских в этом регионе. В качестве основных параметров для расчета пессимистического (негативного) сценария мы экстраполировали на среднесрочную (до 2025-2030 гг.) и долгосрочную (до 2050 г.) перспективу показатели рождаемости, смертности, возрастные коэффициенты дожития, среднюю продолжительность жизни населения России в 2010 г. с небольшим их улучшением по десятилетиям анализируемого периода.

При таком сценарии средняя продолжительность жизни как у мужчин, так и у женщин в России за период 2010-2050 гг. должна вырасти примерно на четыре года (соответственно с 63 до 67 и с 74,8 до 79 лет). А коэффициенты дожития для различных возрастных групп российского населения (т.е. прежде всего русских, составляющих около $80 \%$ жителей РФ) улучшаются к середине века на 10-20\% относительно показателей 2010 г.

Для расчета оптимистического сценария мы исходили из предположения, что основные демографические показатели населения страны и русских в течение анализируемого периода будут достаточно ощутимо улучшаться. Предполагается, что к середине века продолжительность жизни в РФ, увеличившись относительно 2010 г. на 1314 лет, станет сопоставимой с современными показателями населения стран Западной Европы и Северной Америки.

Как результат, если при негативном сценарии естественной динамики русские на Северном Кавказе за период 2010-2050 гг. теряли порядка 23-26\% своей численности, то реализация оптимистического сценария позволяла сократить эти потери до 14-16\%.

Таким образом, сочетание различных сценариев естественной и миграционной динамики формирует определенный коридор вероятных демографических возможностей для русских в республиках Северного Кавказа в среднесрочной и более отдаленной перспективе. Сочетание положительного сценария естественной динамики и максимально возможного сокращения оттока (для каждой республики подбиралась его реальная величина) задавало верхнюю границу данного коридора. Негативный сценарий естественной убыли, совмещенный с сохранением значительных масштабов оттока, очерчивал нижний уровень возможной демографической динамики русских.

Представим результаты данных расчетов по отдельным республикам региона.

\section{ЧЕЧЕНСКАЯ РЕСПУБЛИКА}

Перепись 2002 г. зафиксировала в республике только 40,6 тыс. русских, из которых около 24 тыс. относились к федеральной группировке. Таким образом, гражданское население (остатки русского «старожильческого» массива) составляло не более 16 тыс. человек. Их основная масса проживала в небольшом числе населенных пунктов двух надтеречных районов республики (Наурском и Шелковском), а также в самом Грозном. Таким образом, подавляющее большинство поселений Чечни, в том числе и весьма крупных, уже в начале 
XXI века практически не имело русского населения.

К 2010 г. русское население республики сократилось до 24 тыс. человек, прежде всего, за счет сокращения военной группировки, которая, впрочем, по-прежнему представляла значительную величину (только русских в ее составе насчитывалось около 11 тыс.). Таким образом, непосредственно сама русская община (гражданское население) составляла около 13 тыс. человек, сократившись примерно на 20\% в сравнении с 2002 г.

Возрастная структура местных русских, за вычетом пиков, формируемых «федералами» (контрактниками и офицерами), обнаруживает достаточно ровный контур («прямоугольник») с повышенной долей людей среднего и старшего возраста (рисунок 1). Однако данная форма возрастной пирамиды не предполагает быстрого естественного сжатия диаспоры в ближайшие десятилетия.

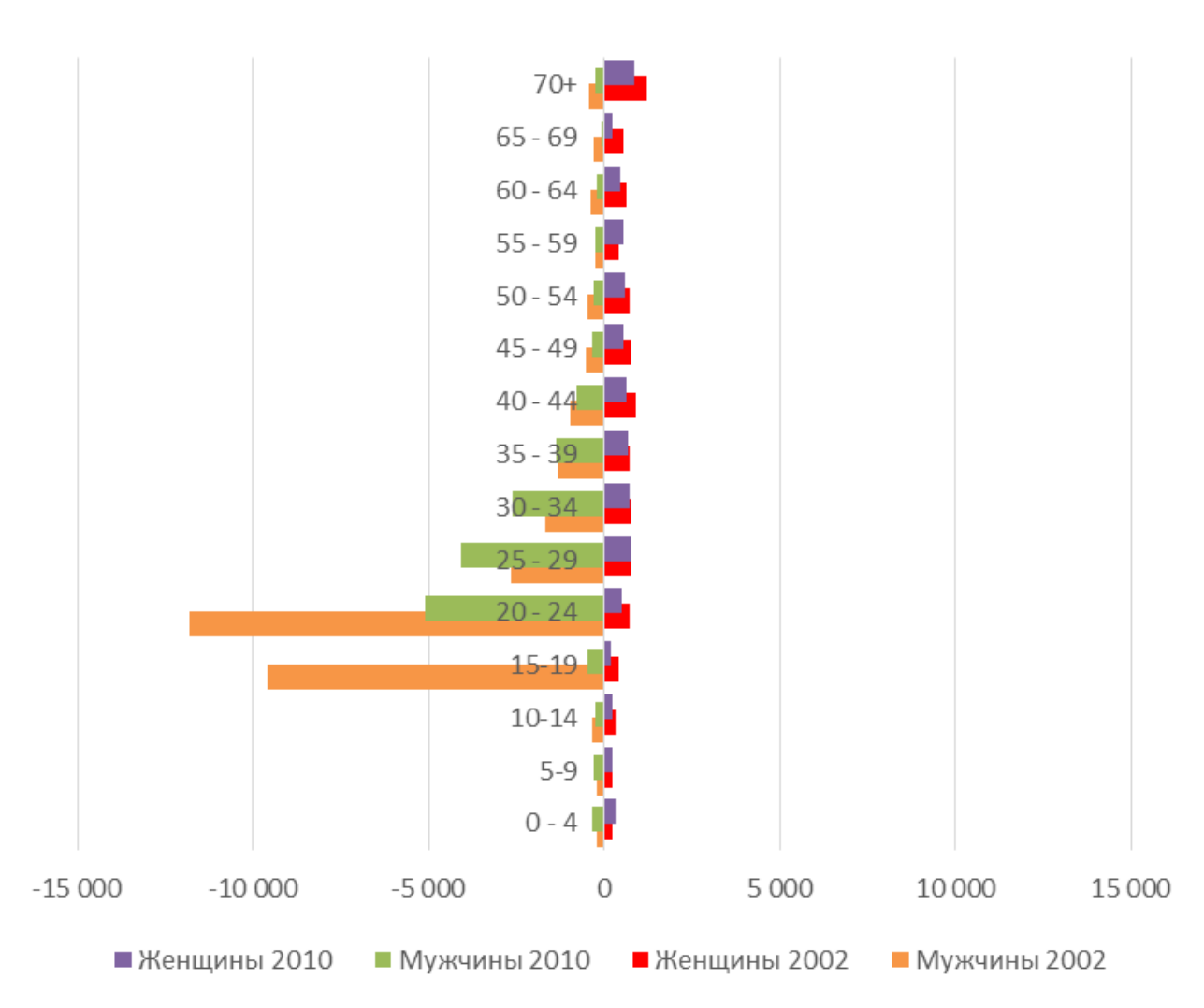

\section{Рисунок 1. Возрастная структура русского населения Чеченской республики, 2002-2010 гг., человек}

Источник: Всероссийская перепись населения 2002 и 2010 годов

Иными словами, если бы проблема оттока русских из республики была решена, то даже столь небольшая диаспора могла сохраняться продолжительное время, включая в 2030-2040 гг. порядка 10-12 тыс. человек (т.е. немногим меньше, чем в настоящее время). Однако дальнейшая миграция русских из республики практически неизбежна. К тому же, чтобы сценарий количественной консервации сработал, общине необходимо поддерживать уровень рождаемости, хотя бы характерный для всего русского населения России. Между тем на одну русскую женщину в активном репродуктивном возрасте (20-39 лет) в 
Чеченской Республике по переписи 2010 г. приходилось 0,76 ребенка в возрасте до 20 лет ${ }^{1}$, тогда как данный показатель по стране у русских составлял 1,28 ребенка.

Основная причина запредельно низкого показателя кроется не в реальной малодетности местных русских женщин, а в межнациональных (русско-чеченских) браках. Основная масса детей в таких смешанных семьях фиксируется переписью по национальности отца в составе титульного народа. Такой принцип национального самоопределения смешанного потомства межнациональных семей, в данном случае, полностью соответствует социальным реалиям республики. В условиях традиционного общества с абсолютной доминантой мужа-отца практически все родившиеся в таких браках дети по своей психоментальной и социокультурной специфике становятся представителями чеченского народа.

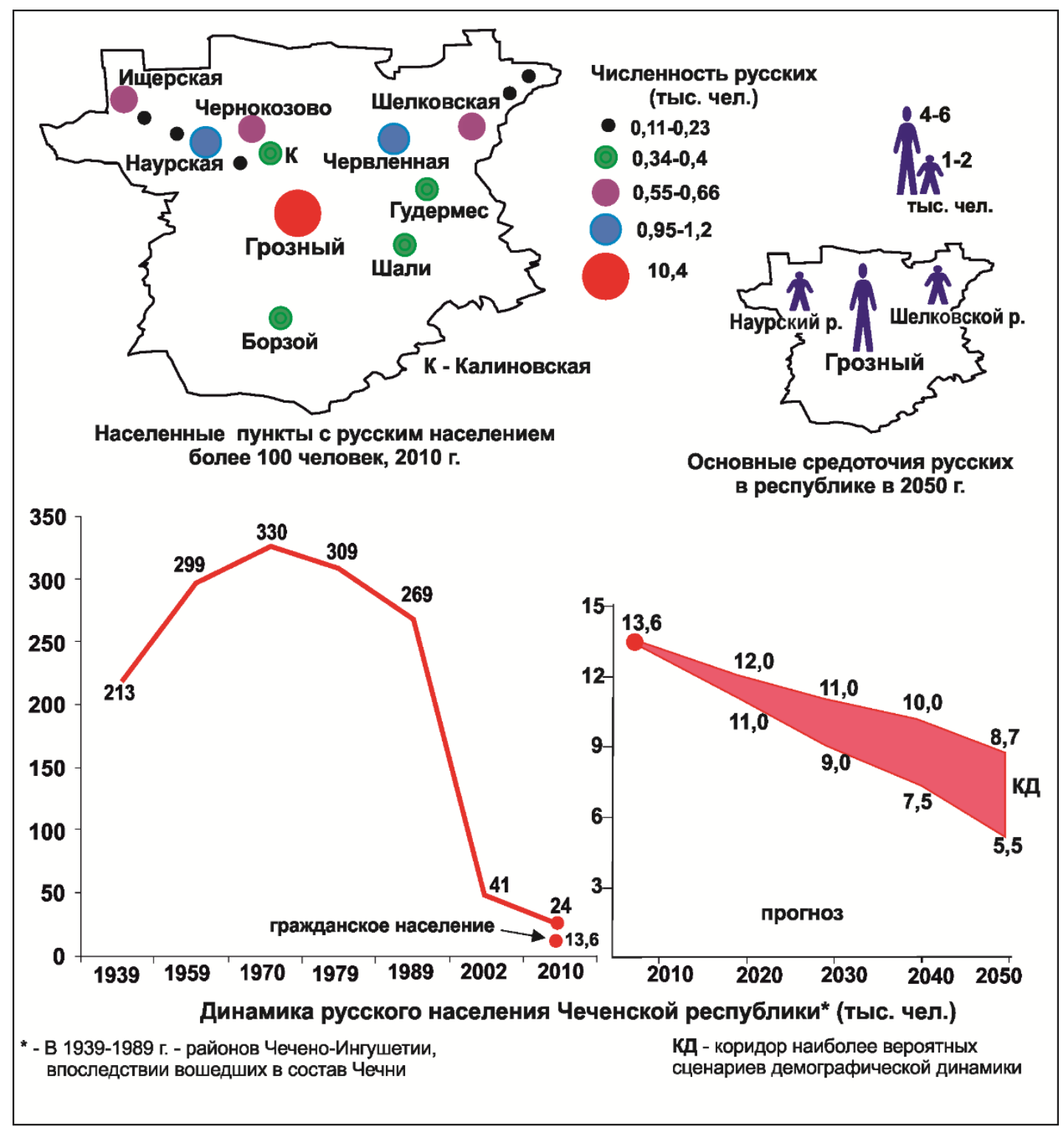

Рисунок 2. Русские в Чеченской Республике, 1939-2050

\footnotetext{
1 За вычетом некоторого числа представителей федеральной силовой группировки - юношей в возрасте 18 19 лет.
} 
Исходя из существующего показателя детности, можно предположить, что до $30 \%$ (не исключено, что и больше) русских женщин активного детородного возраста, проживающих в настоящее время в республике, имеют «титульного» мужа. Следовательно, значительная доля потенциальных мам выпадает из демографического воспроизводства русской общины Чечни.

Между тем и общее число русских женщин детородного возраста в республике с середины текущего десятилетия начинает стремительно сокращаться: во взрослую жизнь вступают малочисленные уроженцы конца XX века. Даже без учета возможной миграции число русских женщин в возрасте 20-39 лет в Чечне к 2020 г. сократится до 1,7 тыс. (с 2,7 тыс. в 2010 г.), а в 2030 г. составит только одну тысячу. Как результат, все будущие генерации русских в республике неизбежно будут в разы меньше, чем группы среднего и старшего возраста.

Наиболее вероятный количественной диапазон демографической динамики русской общины Чечни представлен на рисунке 2. При этом на графике не в полной мере учтена возможная работа ассимиляционного фактора, а следовательно, не исключен и более негативный демографический сценарий.

Впрочем, необходимо учитывать и то, что для «представительских» целей республиканской власти выгодно иметь хотя бы некоторое число поселений с различимым присутствием русских. Для этого было бы разумно поддерживать и сохранять оставшиеся их средоточия, куда при необходимости можно было бы свозить высоких гостей из федерального центра. Данное практическое соображение может несколько продлить срок существования русской общины, сосредоточенной к середине века в ряде поселений северной Чечни и, быть может, в Грозном.

\section{ИНГУШЕТИЯ}

«Русский вопрос» в Ингушетии в геодемографическом аспекте повторяет ситуацию сопредельной Чечни с тем отличием, что в районах советской Чечено-Ингушетии, впоследствии вошедших в состав Ингушетии, русское население изначально было количественно ограниченным. На рубеже 1990-х годов оно составляло около 25 тыс. человек. Порядка 20 тыс. из них покинули республику в первое постсоветское десятилетие.

Перепись 2002 г. зафиксировала в Ингушетии 5,5 тыс. русских. Однако анализ их возрастной структуры позволяет около тысячи человек отнести к федеральной группировке. Таким образом, республиканская русская община могла насчитывать в это время примерно 4,5 тыс. человек. При этом значительная ее часть была компактно сосредоточена в нескольких станицах (прежде всего в Троицкой, Орджоникидзевской, Нестеровской, Вознесенской).

Перепись 2010 г. зафиксировала сокращение русской общины до 3 тыс. человек, следовательно, она в течение «нулевых» сжалась примерно на треть. Учитывая ограниченные масштабы естественной убыли, речь шла о продолжающемся интенсивном миграционном оттоке, который за 2003-2010 гг. мог составить 1-1,5 тыс. человек, притом 
что с начала 2005 г. в республике действовала целевая программа «Возвращение и обустройство русскоязычного населения». Ее нулевые результаты являлись очевидным доказательством того, что «дерусификация» Ингушетии стала свершившимся фактом.

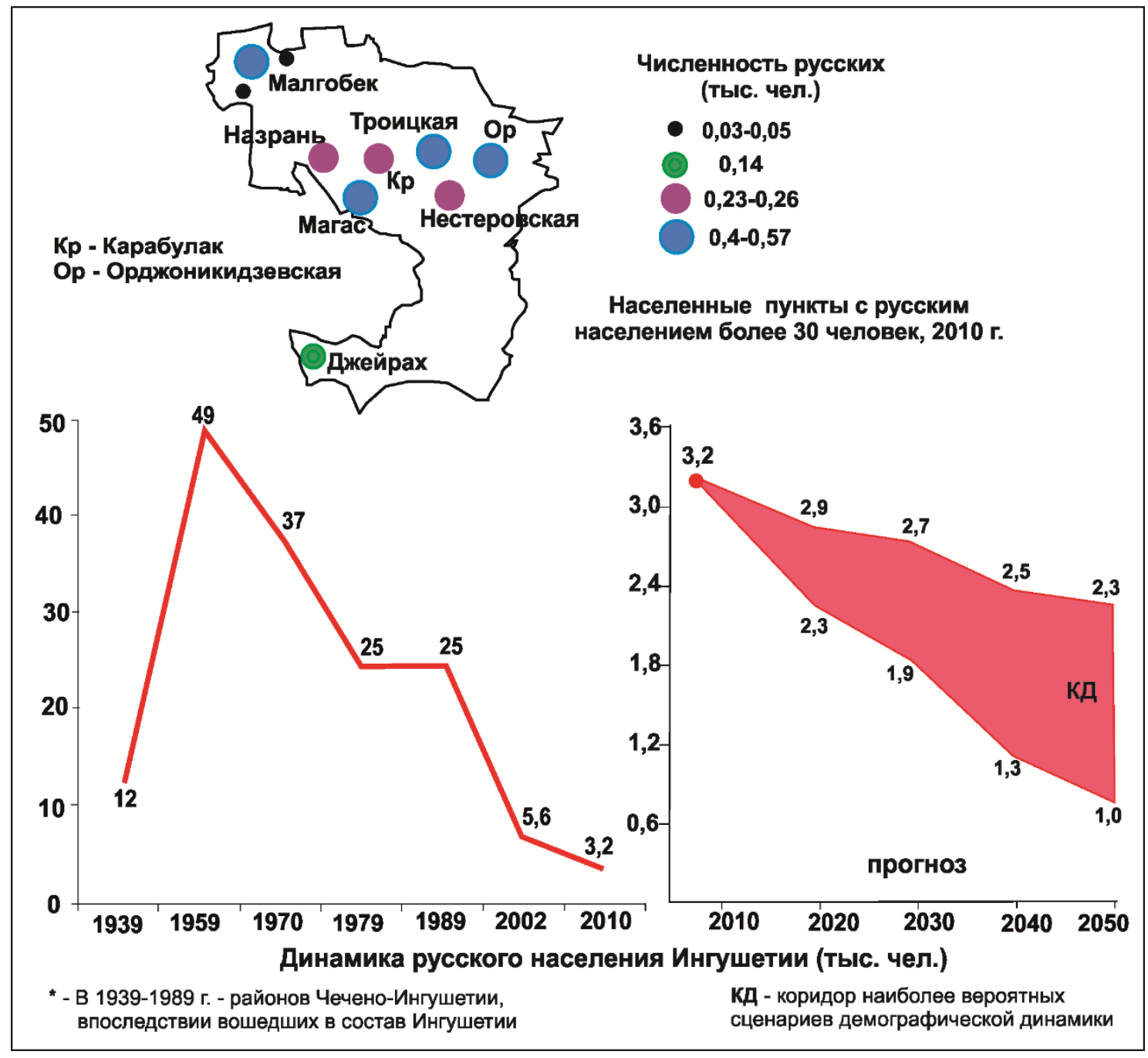

Рисунок 3. Русские в Ингушетии, 1939-2050

Каждая следующая перепись населения России будет фиксировать дальнейшее сокращение местной русской общины, в первую очередь, вследствие дальнейшего оттока и ассимиляции, а не естественной убыли. Согласно переписи 2010 г., у русских в республике на одну женщину активного детородного возраста приходилось только 0,88 ребенка. Причина подобной формальной малодетности та же, что и в соседней Чечне. Соответствующие расчеты позволяют предположить, что в настоящее время в Ингушетии порядка 20-25\% русских женщин репродуктивного возраста состоят замужем за ингушами, т.е. «работают» на демографию титульного народа. Быстрое количественное сокращение общины в такой ситуации неизбежно даже без учета миграции (рисунок 3). При этом нижний край показанного на картосхеме количественного диапазона рассчитан для меньшего оттока русских из республики, чем существовал в первом десятилетии XXI века. А сохранение миграции на уровне 2000-х годов при участии ассимиляционного фактора и естественной убыли уже к 2030 г. сократит местную русскую общину до нескольких сот человек. В этом случае к середине века русское население республики, за вычетом 
командированных силовиков, будет представлено небольшой группой стариковстарожилов и минимальным числом случайных людей, занесенных в Ингушетию прихотью жизненных обстоятельств.

\section{ДАГЕСТАН}

Самым существенным образом продвинулась в направлении сокращения числа русских и третья республика Северо-Восточного Кавказа - Дагестан. Период количественного сокращения русского населения в Дагестане насчитывает уже более полувека, но максимально активизировался этот процесс в постсоветские десятилетия. На его пике, в середине - второй половине 1990-х годов, республику ежегодно покидало до 4-6 тыс. русских. К 2010 г. эта цифра сократилась до 1-1,5 тыс. человек.

В первые годы XXI века масштабы оттока снижаются до 1,5-2 тыс. человек, в 2003 2005 гг. составляют ежегодно 1,2-1,5 тыс. [Дагестан-2005 ...: 15]. С середины 2000-х годов в республике запускается в реализацию программа «Север», направленная на возвращение русского населения. Однако и во второй половине «нулевых» миграционный отток русских из Дагестана составлял порядка тысячи человек в год и заметно превышал их естественную убыль.

Перепись 2010 г. зафиксировала в республике 104 тыс. русских (101 тыс. без учета воинских подразделений). Таким образом, за период 2002-2010 гг. община сократилась на 14 тыс. человек, из которых естественная убыль не превышала 4-5 тыс. человек.

Анализируя возможные перспективы русской общины, необходимо учесть географическую узость ее современного присутствия в республике. Самая значительная часть Дагестана уже в настоящее время практически лишена русского населения. В половине сельских районов республики группы русских составляют не более 20-30 человек (десятые, а иногда - сотые доли процента населения). Из почти 1500 тыс. поселений республики в 2010 г. русские полностью отсутствовали или имелись в минимальном числе (1-2 человека) в 1124 (3/4 поселенческой сети республики). Если же принять в расчет населенные пункты, в которых русских оставалось всего несколько (3-10) человек, доля «дерусифицированных» поселений поднимается до 90\%.

Около $60 \%$ республиканских русских сосредоточено в столичной агломерации (Махачкале и Каспийске) и Кизляре. А с учетом Дербента и Хасавюрта и двух северных районов (Кизлярского и Тарумовского) эта доля вырастает до 80\%.

Вместе с тем современная возрастная «пирамида» русских Дагестана (рисунок 4) имеет форму прямоугольника, т.е. почти не отличается от ее федерального варианта и не предполагает быстрого демографического сжатия в ближайшие десятилетия. Но два фактора (как и в двух вайнахских республиках) - миграционный и ассимиляция - будут существенно ускорять ее сокращение.

Фиксируемая демографической статистикой пониженная детность русских женщин в Дагестане (0,98 ребенка на одну женщину в возрасте 20-39 лет) выражена не так отчетливо, как в Чеченской Республике и Ингушетии. Но и она свидетельствует о том, что 
в настоящее время порядка 15-20\% местных русских женщин состоят в межнациональных браках.

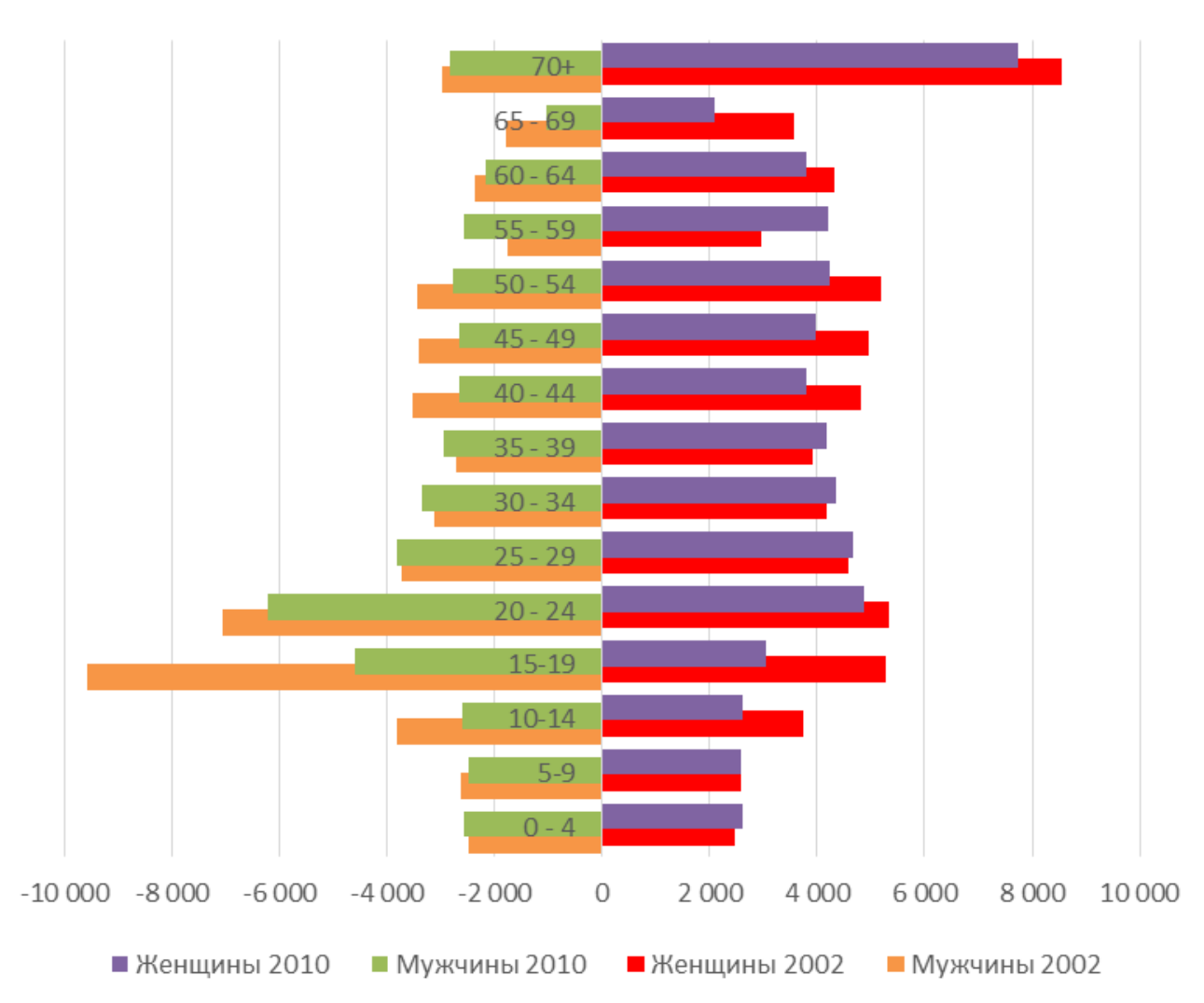

Рисунок 4. Возрастная структура русского населения Дагестана, 2002-2010 гг., чел.

Источник: Всероссийская перепись населения 2002 и 2010 годов

Существенную роль в нисходящей демографической динамике местных русских, очевидно, будет играть и миграция. Сложная этнополитическая и социальноэкономическая ситуация в республике, как и сама сложившаяся миграционная тенденция, практически предопределяют дальнейший отток русских из республики. Под вопросом только его масштабы. При сохранении на долговременную перспективу ежегодных темпов миграции на существующем уровне (до $1 \%$ от общей их численности) и негативном сценарии естественной динамики (нижняя планка коридора демографических возможностей) число русских в Дагестане к 2030 г. может опуститься до 75 тыс. человек, а к середине века будет составлять менее 50 тыс. (рисунок 5).

Но даже реализация сценария минимальной естественной убыли при трехкратном сокращении интенсивности оттока (около $0,3 \%$ в год) приведет к сокращению русского населения Дагестана к 2050 г. до 75 тыс. человек.

Таким образом, диапазон вероятной демографической динамики русского населения Дагестана нельзя назвать катастрофическим, но и оптимизма он не внушает. Составлявшие на рубеже 1960-х годов более 1/5 населения республики, русские к 2040-2050 гг. окончательно превращаются в небольшую по размеру этническую группу (1,5-2,0\% жителей Дагестана), опустившись со второго места (1959 г.) на 8-9-ю позицию в демографическом рейтинге народов республики. Территория расселения русских в 
середине XXI века, по сути, будет ограничена Махачкалой, Кизляром и двумя северными районами Дагестана.

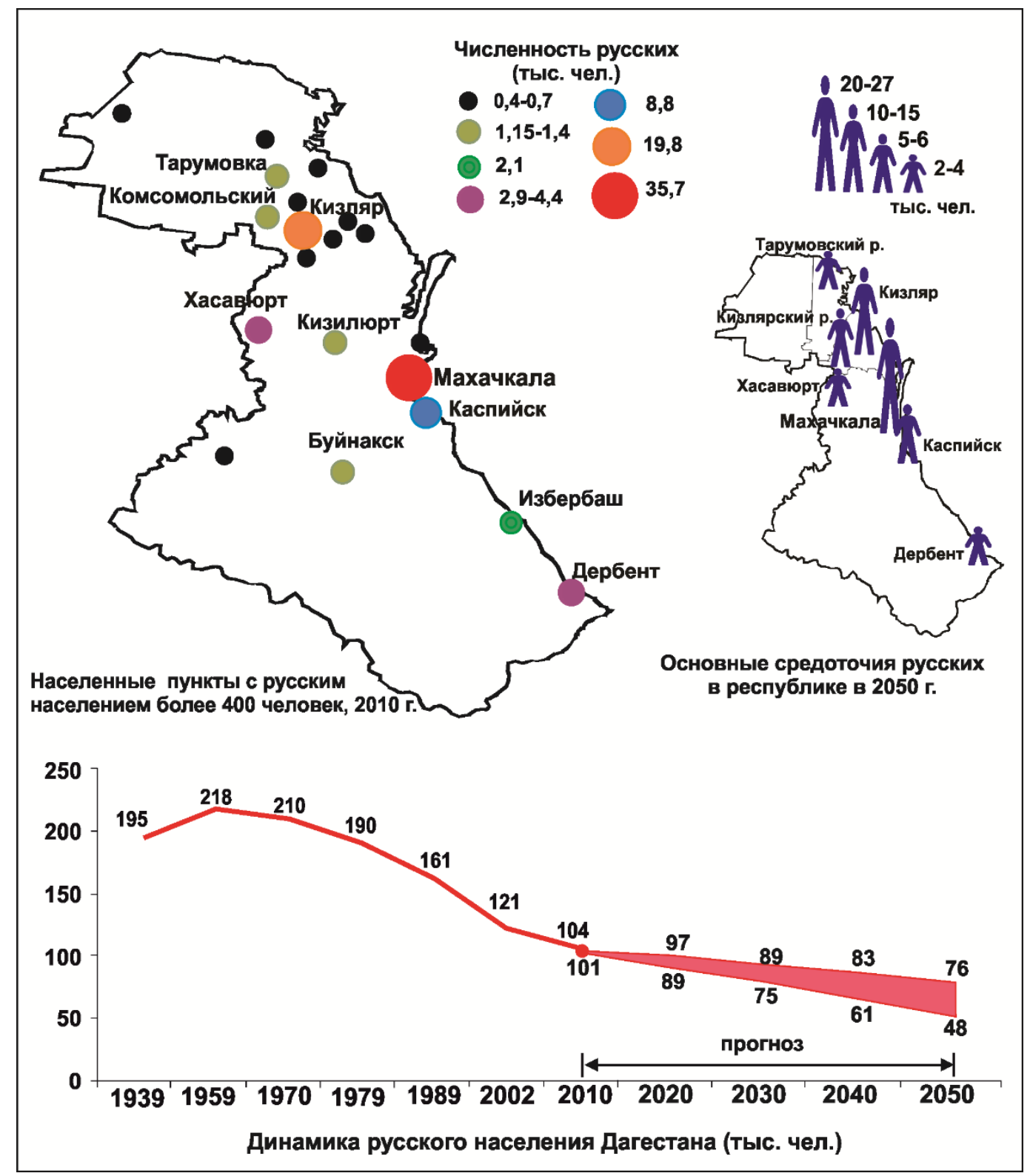

Рисунок 5. Русские в Дагестане, 1939-2050

\section{СеВеРНАЯ ОСЕТИЯ}

«Русский вопрос» в Северной Осетии стоит не так остро, как на Северо-Восточном Кавказе. Русских здесь достаточно много, и они продолжают оставаться второй по численности этнической группой республики. Однако их демографическая убыль оставалась устойчивой тенденцией на протяжении всего постсоветского периода. В 1990-е годы ежегодный отток, согласно А.Б. Дзадзиеву, держался на уровне 0,8-1,0 тыс. человек, и общее сокращение русского населения в республике в 1989-2002 гг. (на 24 тыс. человек) было в равной степени обусловлено естественной убылью и миграцией [Дзадзиев 2008: 133-137]. 
Но есть все основания полагать, что реальный отток русских был еще большим. Перепись 2002 г. зафиксировала в республике 165 тыс. русских. Однако анализ их возрастной структуры позволяет отнести порядка 11,5 тыс. человек к федеральной группировке. Таким образом, «гражданская» русская община Северной Осетии в начале XXI века насчитывала 153-154 тыс. человек и реальное ее сокращение за период 1989-2002 гг. могло составлять порядка 34-35 тыс. человек, что указывает на значительно более высокие темпы миграции, которые на пике российского системного кризиса (первая половина - середина 1990-х годов) могли достигать 2 тыс. человек в год, а к рубежу нового столетия должны были сократиться до ежегодных 1-1,5 тыс.

Отток русского населения в это время был почти повсеместным. Активно уезжали из Владикавказа и других республиканских городов, оставляли сельские территории. Тенденция оттока русских из Северной Осетии сохранилась и в первом десятилетии XXI века. По переписи 2010 г. в республике оставалось более 147 тыс. русских, из которых порядка 4,5 тыс. представляли федеральную группировку. Тем самым, старожильческое население составляло около 143 тыс. человек, сократившись за межпереписной период на 10-11 тыс. человек. Порядка 6-7 тыс. из этого числа могло приходиться на естественную убыль, около 4-5 тыс. человек составила миграция (среднегодовой уровень - 500-600 человек). Таким образом, отток русских значительно сократился в сравнении с первым постсоветским десятилетием, однако оставался устойчивой тенденцией, заметно ускоряющей демографическое сжатие местной русской общины.

Анализируя причины миграции русского населения из республики, исследователи, как правило, концентрируют внимание на экономических факторах. Учитывая высокий уровень социокультурной модернизации и православие значительной части титульного населения Северной Осетии-Алании, других серьезных причин для интенсивного оттока, на первый взгляд, быть не должно. Однако системная этнизация республиканского общества в полной мере дает о себе знать и в постсоветской Осетии. И социологические опросы фиксируют отчетливое понимание местными русскими своей социальной бесперспективности («второсортности»), не позволяющей им на равных с титульным населением бороться за статусные позиции [Северный Кавказ... 2010: 24].

Устойчивый отток русских из республики свидетельствует как раз о том, что полного их привыкания к нарастающей маргинализации своего социального статуса не произошло. Точней, просматриваются очевидные возрастные различия: если старшее поколение так или иначе смирилось со своими статусными потерями, то значительная часть молодежи (около трети) ориентирована на отъезд в «большую» Россию. Именно молодежь и составляет значительную часть современной русской миграции из Северной Осетии.

Таким образом, динамика русского населения в республике, как в ближайшей (до 2020 г.), так и более отдаленной перспективе с большой вероятностью будет определяться сдвоенной «работой» естественной убыли и миграции. Причем существующая возрастная структура русской общины указывает на то, что в текущем десятилетии более значимую роль в ее демографическом сжатии может играть естественная убыль. По переписи 2010 г. в Северной Осетии старшая возрастная группа (люди 70 и более лет) составляла среди 
русских 12,6\%, а с учетом пожилого населения (60-69 лет) - 23\% (рисунок 6). Для всего русского массива по РФ данные показатели составляли соответственно 10,4 и 19\%.

Между тем в детородный возраст уже вступают малочисленные поколения, родившиеся в 1990-е годы. Достаточно сказать, что в республике число русских женщин активного репродуктивного возраста (20-39 лет) с 22,2 тыс. в 2010 г. сократится к 2020 г. до 18,3 тыс., а в 2030 г. составит только 14,6 тыс. (и это без учета миграционного фактора). При столь значительном сокращении численности потенциальных «мам» практически невозможно рассчитывать на рождаемость, способную полностью возместить естественную убыль населения. Однако, если предположить, что на одну русскую женщину репродуктивного возраста в республике в 2020-2030-е годы будет приходиться порядка 1,71,8 деторождений, община, без учета фактора миграции, может в ближайшие десятилетия сокращаться очень медленными темпами.

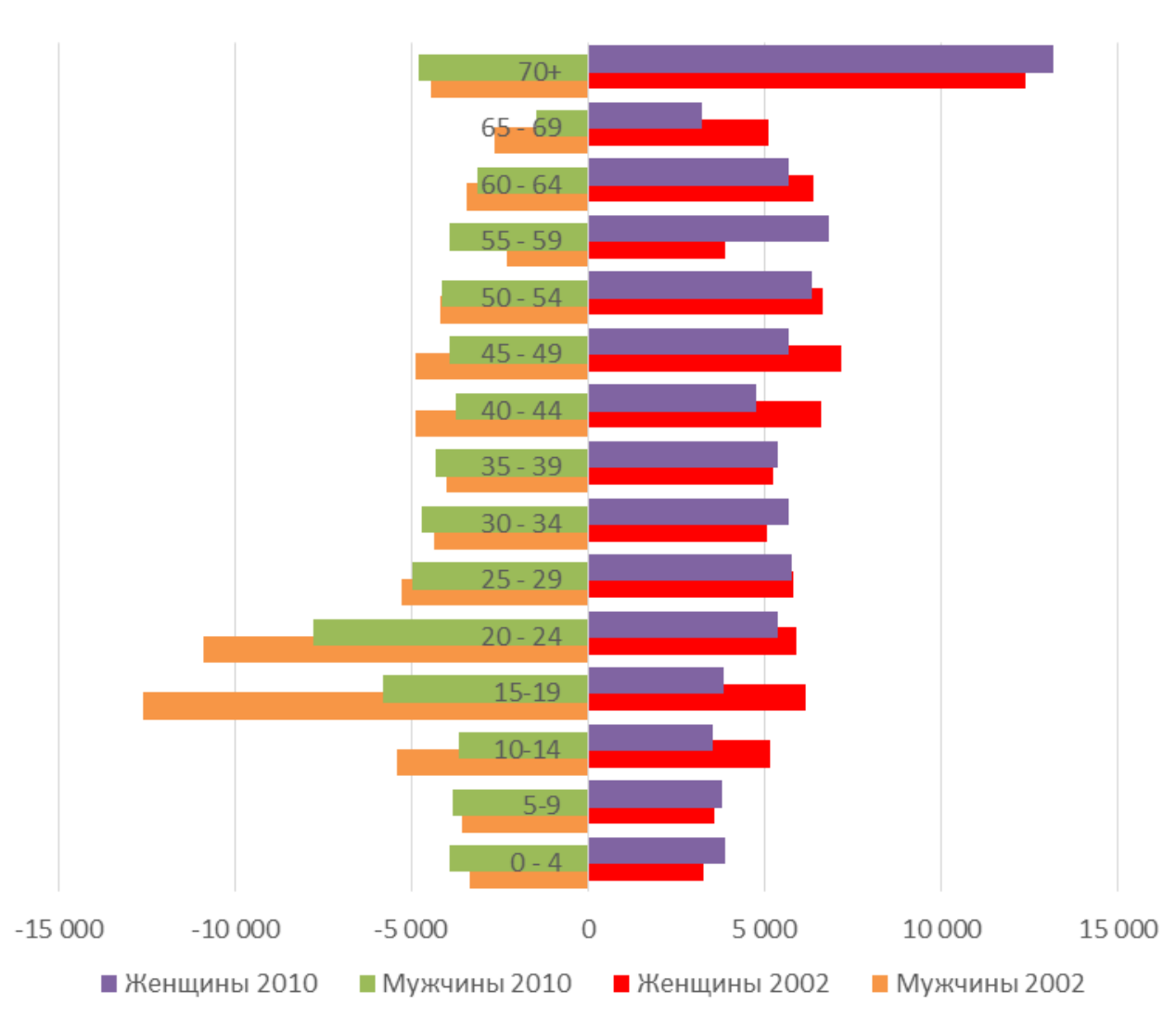

Рисунок 6. Возрастная структура русского населения Северной Осетии, 2002-2010

Источник: Всероссийская перепись населения 2002 и 2010 годов

Показательно, что соотношение детей и женщин репродуктивного возраста у русских в республике совпадает с общероссийским показателем - свидетельство того, что ассимиляционный фактор, столь отчетливо фиксируемый в республиках СевероВосточного Кавказа, не играет значимой роли в демографической динамике русского населения Северной Осетии. Общая религия, сближенный уровень социокультурной модернизации существенным образом сглаживали работу данного фактора (т.е. смешанное потомство русско-осетинских браков более равномерно распределялось между двумя национальностями). 
Но остается еще фактор миграции. С большой вероятностью отток сохранится и на всю обозримую перспективу. При сохранении его современных масштабов русская община может терять по несколько тысяч человек каждое десятилетие и к середине века составлять менее 100 тыс. человек (рисунок 7).

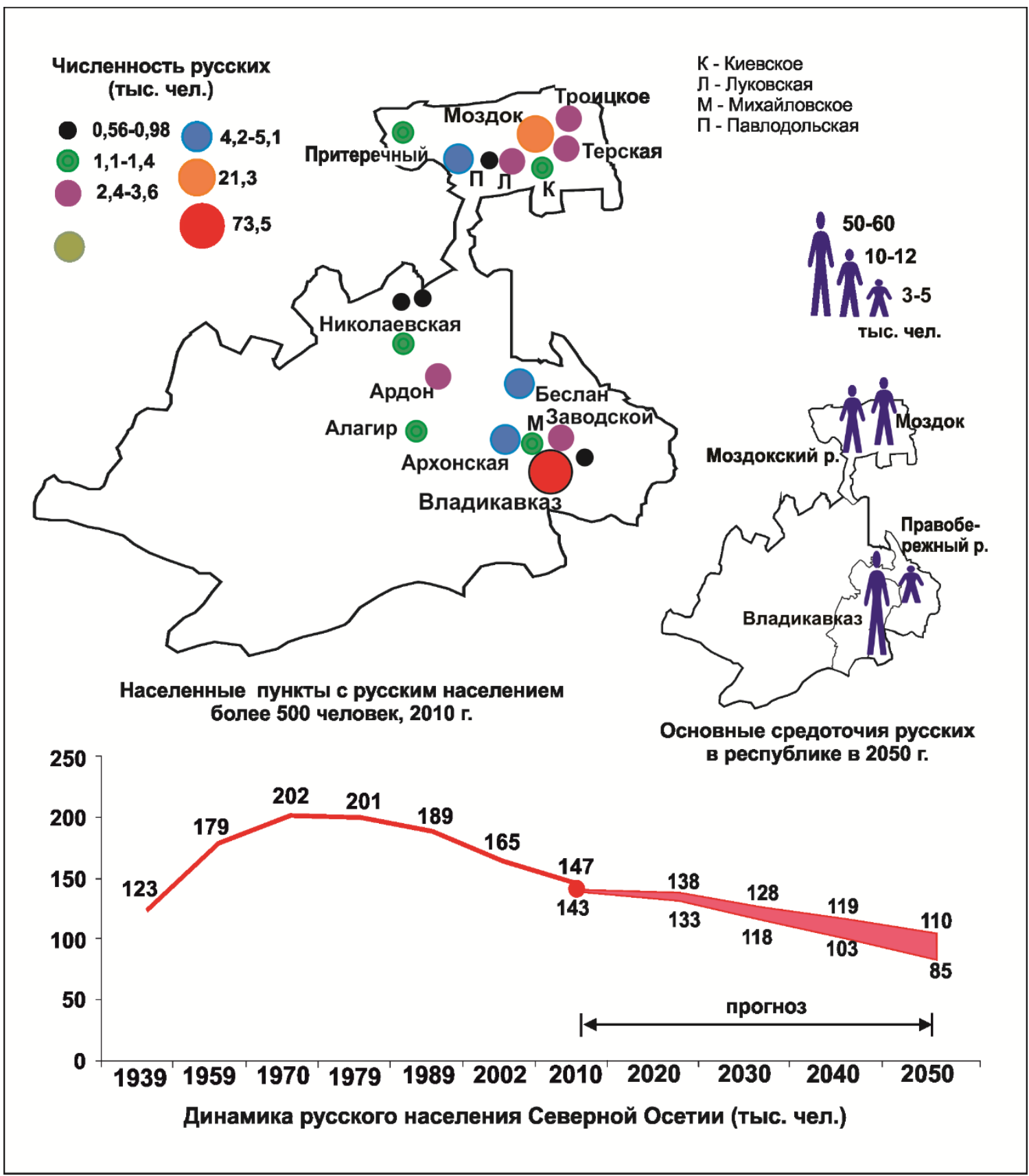

Рисунок 7. Русские в Северной Осетии, 1939-2050

Значение, однако, имеют не только количественные масштабы оттока, но и ухудшение возрастной структуры остающихся русских. Роль данного показателя в демографической депопуляции республиканской общины на протяжении ближайших 15-25 лет может быть незаметной. Но по истечении этого периода последствия могут оказаться едва ли не катастрофическими: в середине века численность русских может начать «таять» со скоростью 3-4\% в год. Впрочем, данный сценарий предполагает не только устойчивый 
отток, но и столь же устойчивую миграционную потерю заметной доли местной русской молодежи.

В настоящее время география русского населения в республике преимущественно ограничена Владикавказом и Моздоком с Моздокским районом. В сумме на эти два центра и район приходится более $80 \%$ всех местных русских. При этом в 71 населенном пункте (почти 38\% всей республиканской поселенческой сети) русских нет или число их минимально (1-2 человека). А с учетом тех населенных пунктов, в которых число русских составляет всего 3-10 человек, половина системы расселения по сути оказывается лишенной русского этнокультурного присутствия (по данному показателю Северная Осетия тяготеет к глубоко «дерусифицированному» Северо-Восточному Кавказу). И в перспективе география русских в республике будет продолжать сжиматься, всё более ограничиваясь столицей и Моздокским районом.

\section{КАБАРДИНО-БАЛКАРИЯ}

Еще в начале 1970-х годов русские составляли $37 \%$ населения республики и по численности совсем немного уступали кабардинцам, причем количественный рост русского населения продолжался вплоть до конца советского периода (240 тыс. в 1989 г.).

Перепись 2002 г. зафиксировала в Кабардино-Балкарии 226,2 тыс. русского населения. Следовательно, за период 1989-2002 гг. его численность должна была сократиться всего на 14 тыс. человек, из которых, согласно А. Б. Дзадзиеву, 12 тыс. пришлось на естественную убыль и только 2 тыс. - на миграционный отток [Дзадзиев 2008: 131]. Впрочем, он же в другой публикации дает совсем иные цифры: только в 1989-1998 гг. республику покинуло порядка 7,7 тыс. русских [Дзадзиев 2007: 57]. На деле это расхождение может означать, что результаты переписи 2002 г. в Кабардино-Балкарии были завышены не только по титульным народам, но и по русским.

Есть все основания полагать, что общие миграционные потери русского населения в 1989 - 2002 гг. могли составлять порядка 10 тыс. человек. Следовательно, и численность русских в республике в 2002 г. была порядка 220 тыс. (за вычетом воинского контингента - около 218-219 тыс.).

Данное предположение отчасти подтверждается дальнейшей динамикой русской общины. Согласно переписи 2010 г., численность русских в республике составила 193 тыс. человек - на 34 тыс. меньше, чем в 2002 г. Если исходить из этих цифр, придется констатировать существенный рост миграционного оттока русских из республики в 2000-е годы. Учитывая размеры естественной убыли (порядка 9-11 тыс. человек), миграция должна была составить в 2002-2010 гг. 23-25 тыс. человек (около 3 тыс. ежегодно). Иными словами, интенсивность оттока выросла в несколько раз по сравнению с первым постсоветским десятилетием. Едва ли это соответствует действительности.

Но несомненно, что миграционные потери русских в 2000-е годы были действительно велики. По данным республиканской миграционной службы, в 2005-2007 гг. 
они ежегодно составляли около 2 тыс. человек. Соответственно за весь межпереписной период отток мог составить порядка 15-16 тысяч.

Итак, демографическое сжатие русской общины было более равномерным, чем это следует из официальных результатов постсоветских переписей (21-22 тыс. для 1989-2002 гг.; 25-26 тыс. человек для 2002-2010 гг.). Но и данный результат не отменяет главного вывода: в целом благополучно прошедшая через 1990-е годы республика в стабильные «нулевые» стала одним из регионов-лидеров по масштабам оттока русских с Северного Кавказа.

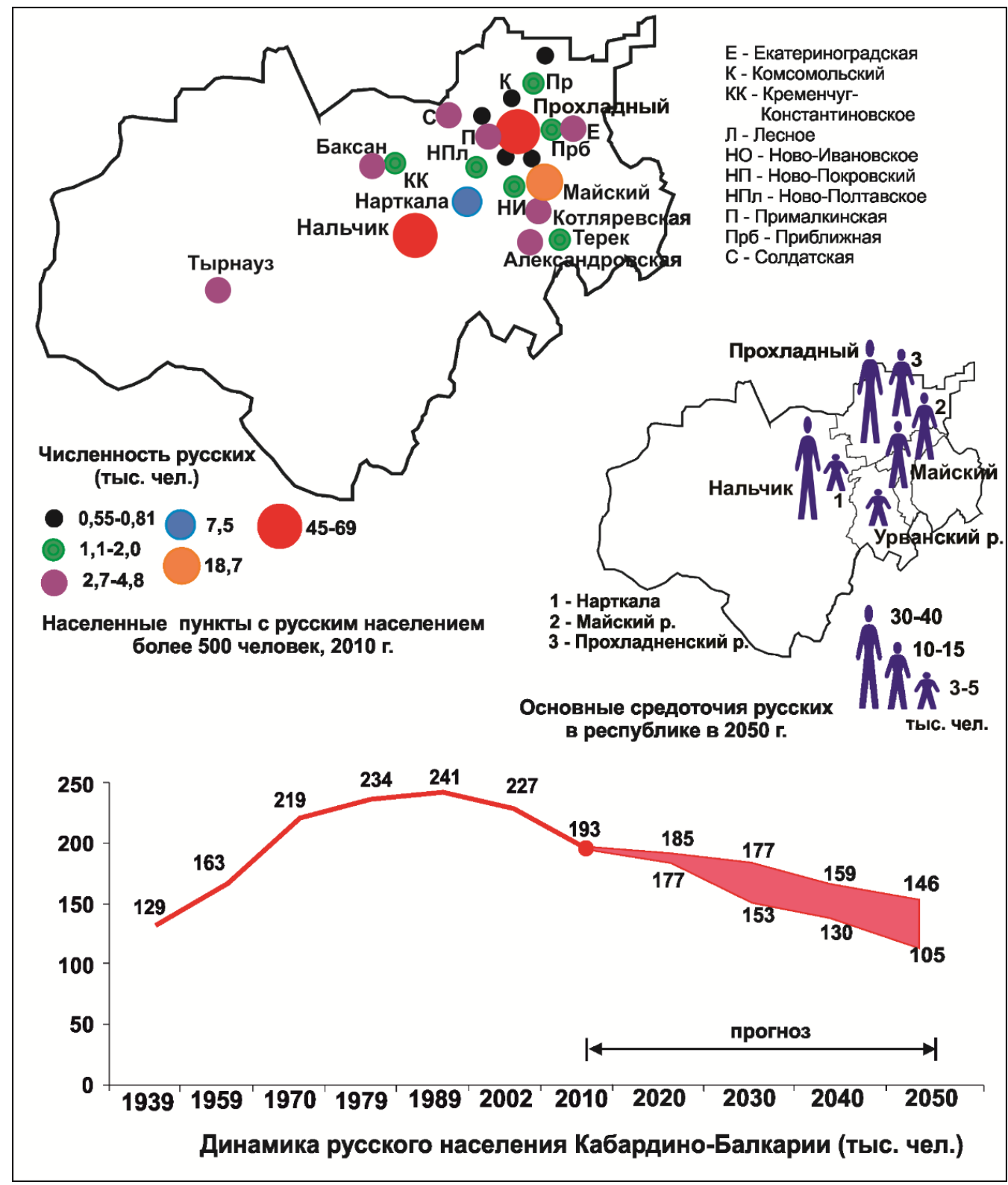

Рисунок 8. Русские в Кабардино-Балкарии, 1939-2050

На миграцию в 2000-е годы приходится 60-70\% демографического сокращения местного русского населения. Причем наиболее интенсивно (как и в Северной Осетии) республику покидала молодежь. Расчет естественной динамики русской общины в 2000-е годы с учетом коэффициента дожития различных возрастных групп позволяет определить их миграционные потери. В группе 20-летних (20-29 лет) отток составил порядка 3,5 тыс. 
человек, среди 30-летних (30-39 лет) - более 8 тыс. Иными словами, русская миграция в первую очередь состояла из молодежи и людей среднего возраста.

Сохранение данной тенденции на перспективу постепенно формирует возрастную структуру населения с большой долей пожилых и старых людей. В полной мере негативное влияние подобной трансформации республиканской общины может начать сказываться на ее демографической динамике только во второй трети века. Но уже существующий в настоящее время контур возрастной пирамиды предполагает заметный рост естественных потерь во втором половине текущего десятилетия, когда массово начнут уходить из жизни представители наиболее крупной группы республиканских русских - люди от 70 лет и старше. В 2010 г. на них приходилось 12,4\% русского населения Кабардино-Балкарии.

Однако центральную роль в демографическом сжатии русского массива республики, как уже отмечалось, в настоящее время играет миграция. Сохранение ее в ближайшие десятилетия на уровне $1 \%$ (до 2 тыс. человек в год) способно обернуться коллапсом русской общины уже к середине XXI века. Впрочем, вероятность подобного демографического сценария близка к нулю. Более вероятным представляется снижение масштабов оттока. При сокращении его ежегодных темпов оттока до 0,7\% и негативном сценарии естественной динамики, численность русских в Кабардино-Балкарии к середине века может опуститься к 100-тысячной отметке (рисунок 8).

Положительный вариант естественной динамики и миграция на уровне $0,3 \%$ в год позволят русской общине в 2050 г. сохранять численность на уровне 145-150 тыс. человек. В этом случае, существенно сократившись в числе и доле, русские в демографическом рейтинге народов республики все еще будут оставаться на второй позиции, опережая балкарцев.

География местных русских будет сохранять свои основные контуры при любом демографическом сценарии. Уже в настоящее время она является очень узкой - 90\% всех русских республики сосредоточено в Нальчике и двух северо-восточных районах (Прохладненском и Майском), занимающих только шестую часть территории КабардиноБалкарии. Данные районы и республиканская столица останутся основными средоточиями русского населения и в середине XXI века.

\section{КАРАЧАЕВО-ЧЕРКЕСИЯ}

На протяжении второй половины XX века русские являлись крупнейшим народом Карачаево-Черкесии. И хотя их доля в населении, начиная с 1959 г., сокращалась, общая численность продолжала расти до конца 1980-х годов. Еще в 2002 г. русские составляли более трети жителей республики. Вместе с тем по темпам оттока русских в 1989-2002 гг. республика отставала только от Чечни и Дагестана - около 18 тыс. человек (порядка 1,5 тыс. в год).

Социально-экономическая стабилизация 2000-х годов на интенсивности этой миграции практически не сказалась. Экспертная оценка русской миграционной убыли за 2002-2010 гг. дает цифру 11-12 тыс. человек (те же 1,5 тыс. в год). А с учетом естественной 
убыли совокупные демографические потери республиканских русских в данный период должны были составить 17-18 тыс. человек.

Тем удивительней оказались данные переписи 2010 г., согласно которым численность русских в республике составила 150 тыс., т.е. выросла на тысячу человек. Очевидно, что данная цифра имеет слабое отношение к действительности, реальное число русских в республике может составлять порядка 130 тыс., около $80 \%$ которых в настоящее время сосредоточено в Черкесске в двух западных районах - Зеленчукском и Урупском (рисунок 9), т.е., как и во всех остальных республиках, русское население размещено по территории Карачаево-Черкесии очень неравномерно.

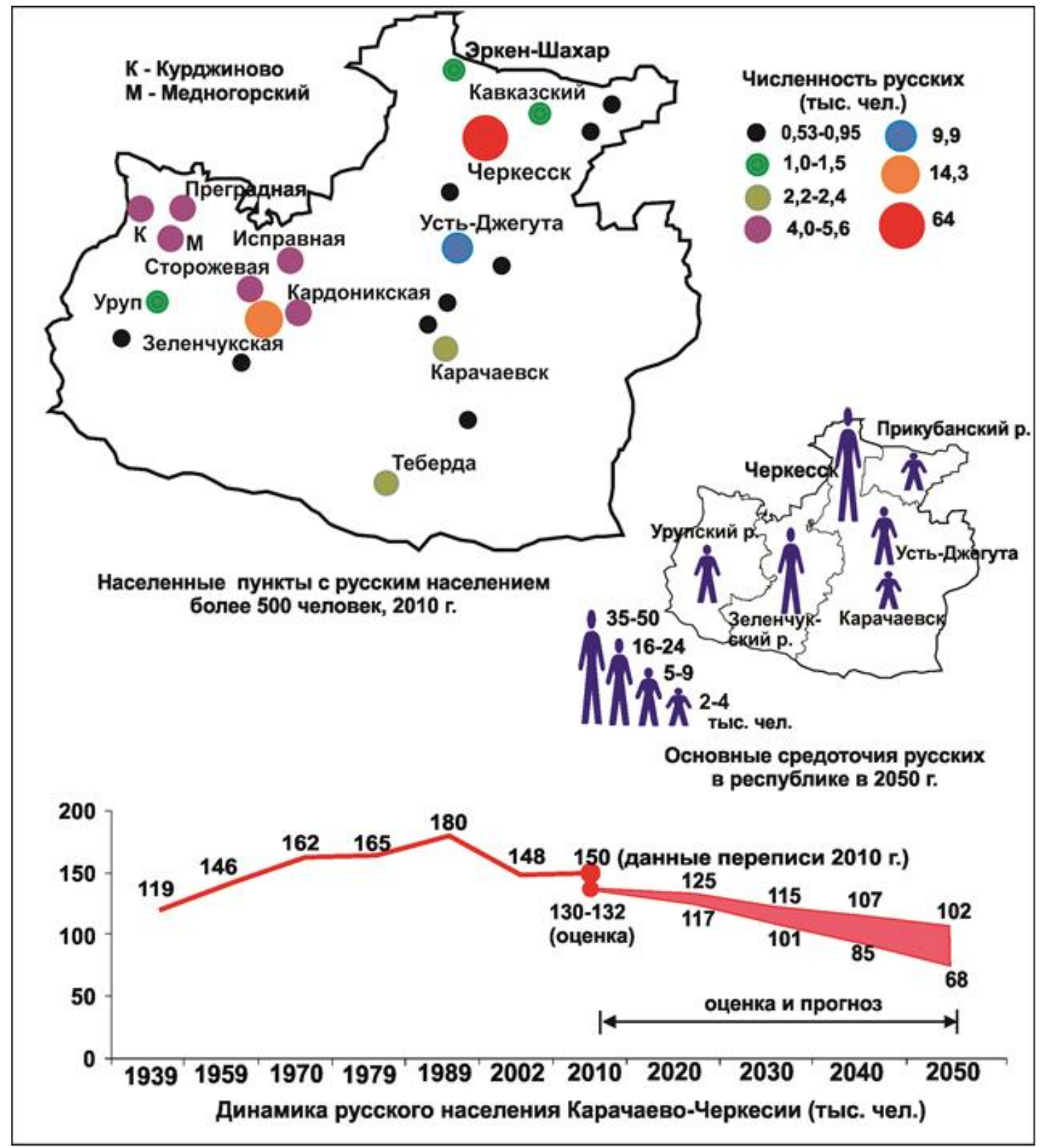

Рисунок 9. Русские в Карачаево-Черкесии, 1939-2050

Сделанные в 2010 г. приписки существенно затрудняют прогнозные расчеты. Тем более, что проверить их результатами следующих переписей будет едва ли возможно, поскольку эти будущие результаты, скорее всего, станут «заложниками» уже происшедших 
фальсификаций. Действительно, учитывая устойчивое сокращение местного русского населения, перепись 2020 г., проведенная без приписок, должна будет дать цифру, существенно уступающую показателю 2010 г. (ведь помимо демографического сжатия последнего десятилетия должен быть вычтен и приписанный в 2010 г. виртуальный довесок). Подобное резкое сокращение численности русских в республике может быть негативным образом воспринято не только в обществе, но и в структурах федеральной власти, что с большой вероятностью заставит руководство республики не рисковать и прибегнуть к новым припискам.

Расчеты вероятной динамики русского населения Карачаево-Черкесии на среднесрочную и более отдаленную перспективу дают к середине века демографический коридор в диапазоне 70-100 тыс. человек. Верхний уровень задан реализацией положительного сценария естественной динамики и оттоком на уровне ежегодных $0,3 \%$ от численности местных русских. К нижней границе их число сместится при негативном варианте естественной динамики и миграции на уровне $0,8 \%$ в год.

При этом необходимо учитывать деформацию половозрастной структуры. Как и в других республиках, русская миграция из Карачаево-Черкесии формируется преимущественно людьми молодого возраста. А значит, уже во второй половине XXI века местная русская община, критически нарастив долю населения старших возрастов, может в разы увеличить темпы своей естественной убыли и в течение одного - двух десятилетий стать кандидатом на сжатие по дагестанскому сценарию.

\section{АДЫГЕЯ}

Адыгея - единственная из республик Северного Кавказа, в которой русские продолжают оставаться основной этнической группой. Показательно, что даже в 1990-е годы, характеризуемые всплеском местного национализма, Адыгея оставалась привлекательной для русской миграции из других регионов РФ. За период 1989-2002 гг. численность русских сократилась в республике с 297 тыс. до 289 тыс., притом что их естественная убыль составила в это время порядка 15-16 тыс. человек. Таким образом, около половины потерь было компенсировано миграционным притоком.

Минимальными оказались и практические результаты миграционной политики республиканской власти, ориентированной на возвращение потомков черкесовмухаджиров XIX века. Показательно, что даже сирийские черкесы, вынужденные покидать страну охваченную войной, в своем большинстве направлялись в Европу и Турцию. Общие масштабы реэмиграции зарубежных черкесов на весь Северный Кавказ за постсоветский период (т.е. за четверть века) составили несколько тысяч человек, из которых только часть пришлась на Адыгею.

Территориальная «вписанность» республики в пределы Краснодарского края (одного из основных центров притяжения переселенцев со всей РФ) определяла положительное миграционное сальдо Адыгеи и в 2000-е годы. Приток превысил 10 тыс. человек, значительную часть которых составляли русские. 
Данное пополнение должно было восполнить до половины демографических потерь от естественной убыли, которая у русских республики за период 2002-2010 гг. составляла порядка 11-12 тыс. человек. Но в этом случае общая численность русских в Адыгее должна была сократиться за межпереписной период с 288 тыс. до 282-283 тыс. Однако перепись 2010 г. зафиксировала в республике только 271 тыс. русского населения, словно его естественная убыль дополнялась оттоком, что очевидным образом не соответствует миграционной статистике.

Но даже если предположить, что приток русского населения в республику в ближайшие десятилетия сменится оттоком и данная тенденция станет устойчивой, сам масштаб демографического массива русских Адыгеи является надежной гарантией сохранения их в качестве наиболее многочисленного народа региона на самую долгосрочную перспективу (рисунок 10).

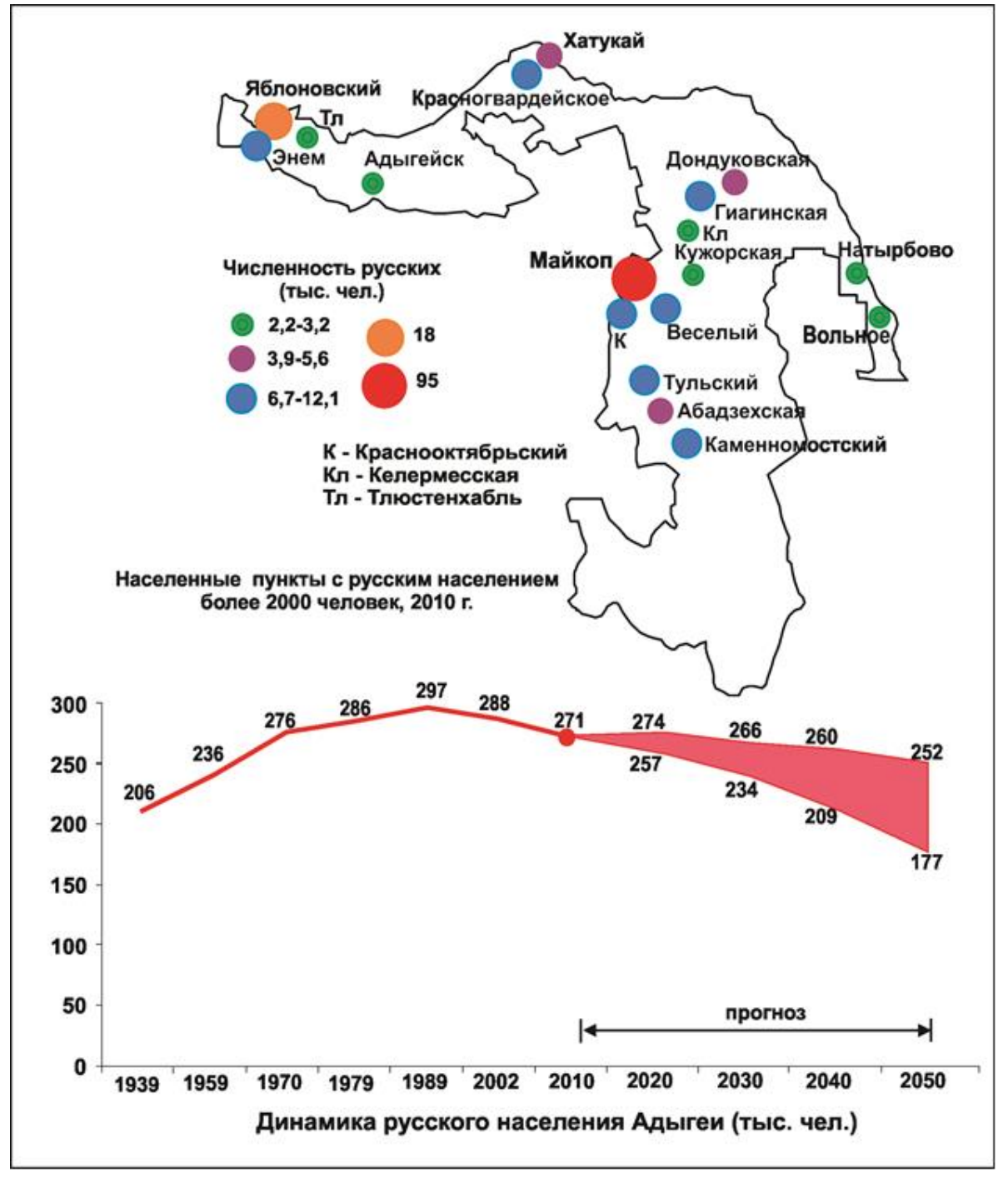

Рисунок 10. Русские в Адыгее, 1939-2050

При ежегодном оттоке в 0,3\% и негативном сценарии естественной динамики численность русских в республике к середине века может опуститься ниже 180 тыс. человек, но по-прежнему в 1,5-1,6 раз будет превышать число титульных адыгейцев. Но Адыгея, повторим, является исключением из всех республик региона. 


\section{Выводы}

Процесс сокращения численности населения в республиках Северного Кавказа, начавшись еще в 1970-е годы, к настоящему время сложился в устойчивый тренд. В существующих этнополитических, социально-экономических и социокультурных реалиях переломить его не представляется возможным. Речь может идти только о его минимизации через сокращение масштабов миграционного оттока русских. Но даже подобное половинчатое решение «русского вопроса» на деле предполагает достаточно серьезную модернизацию Северного Кавказа, последовательно осуществляемую федеральным центром, что также представляется крайне маловероятным, учитывая особенности национальной политики современной российской власти и ее весьма ограниченные проектные способности.

Это означает, что характерный для всей РФ процесс естественной убыли русских на Северном Кавказе будет существенным образом дополняться и ускоряться миграционным оттоком из республик. Именно миграция в ближайшие 2-3 десятилетия сохранится в качестве центрального механизма ускоренного сокращения русского демографического присутствия в республиках региона. При этом существенное значение имеют не только количественные масштабы оттока, но и ухудшение возрастной структуры остающихся русских (основная масса мигрантов - люди в возрасте 20-40 лет).

Роль миграционного фактора начнет стремительно расти к середине века, когда в группе пенсионеров может оказаться уже порядка 30-40\% всего русского населения республик Северного Кавказа, и тем самым оно вступит в период интенсивного, а спустя еще некоторое время, возможно, и обвального своего сокращения.

Однако естественные потери русских начнут ощутимо расти уже в ближайшем обозримом будущем, поскольку у них во всех республиках (как и по РФ в целом) уже начался процесс поступательного сокращения числа женщин репродуктивного возраста и к 2030 г. их численность сократится на 25-30\% от уровня 2010 г.

Иными словами, в перспективе речь может идти только о разных сценариях сокращения русского населения Северного Кавказа. В настоящее время по своей численности оно уже опустилось к уровню середины 1930-х годов. К 2030 г. при негативном демографическом сценарии в республиках региона может остаться менее 700 тыс. русских, а к середине XXI века- менее 500 тыс. (рисунок 11). Впрочем, не исключен и положительный сценарий, при котором демографические потери окажутся значительно меньшими и численность русских опустится к 2050 г. не ниже 700-тысячной отметки. 


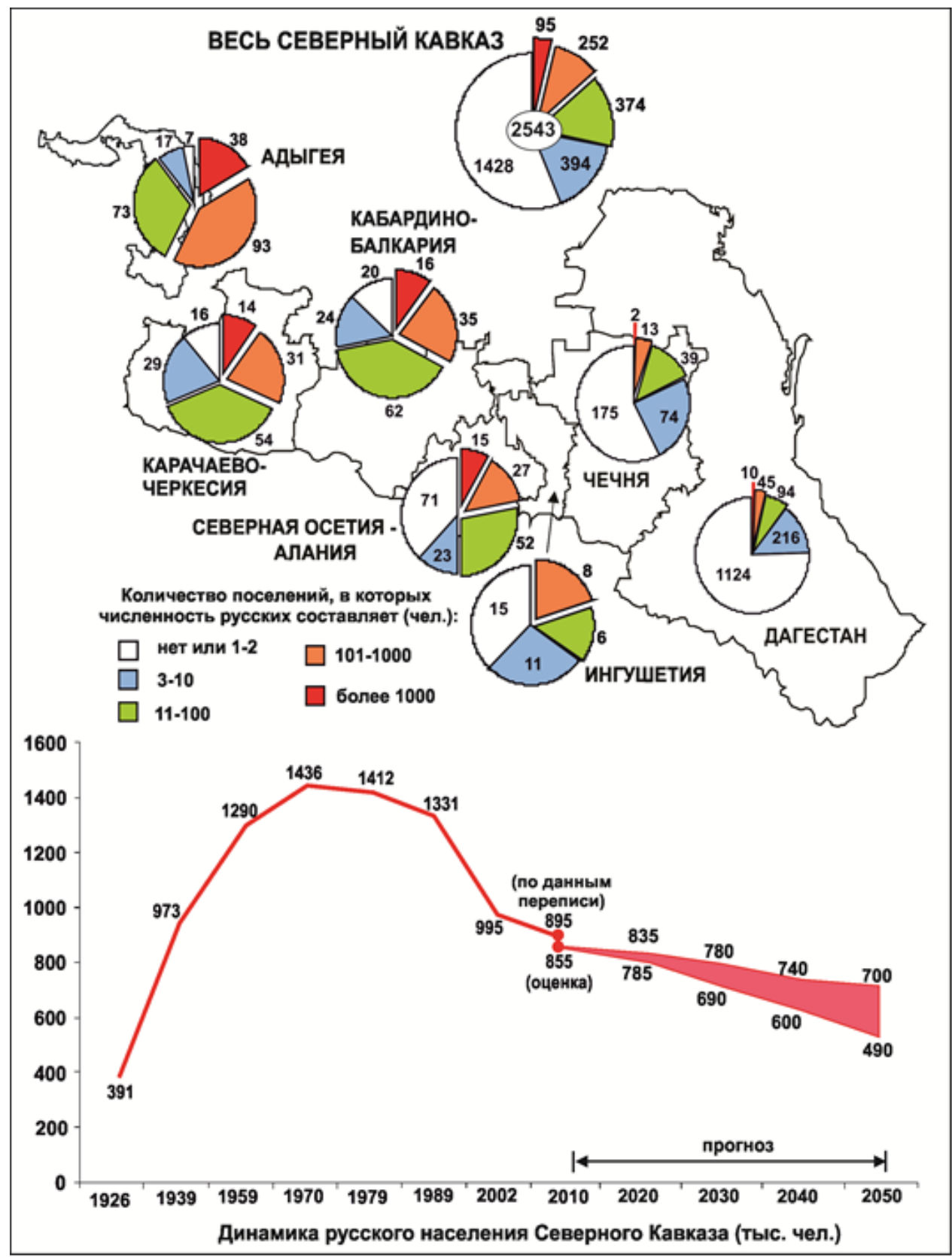

Рисунок 11. Русские на Северном Кавказе, 1926-2050

Практически неизбежным представляется и дальнейшее сокращение «географического» представительства русских. Уже в настоящее время из 2,5 тыс. поселений республиканского Северного Кавказа более 56\% практически лишены русского населения, и только в 358 (14\%) оно представлено территориальными группами более 100 человек. Очевидно, что с течением времени число населенных пунктов без русского населения будет возрастать (прежде всего за счет небольших поселений). При этом будет меняться удельное соотношение различных субрегионов Северного Кавказа. Если в середине XX века почти 44\% русского населения республик проживало на востоке национального региона, то в настоящее время доля трех восточных национальных автономий упала ниже 14\%, а к середине века скорее всего опустится до 11-12,5\%. С 54,6 до 51,4-52,8\% сократится удельный вес русских в центральной части Северного Кавказа (рисунок 12), а доля русского населения западного субрегиона (Адыгея) вырастет до 36\%. 


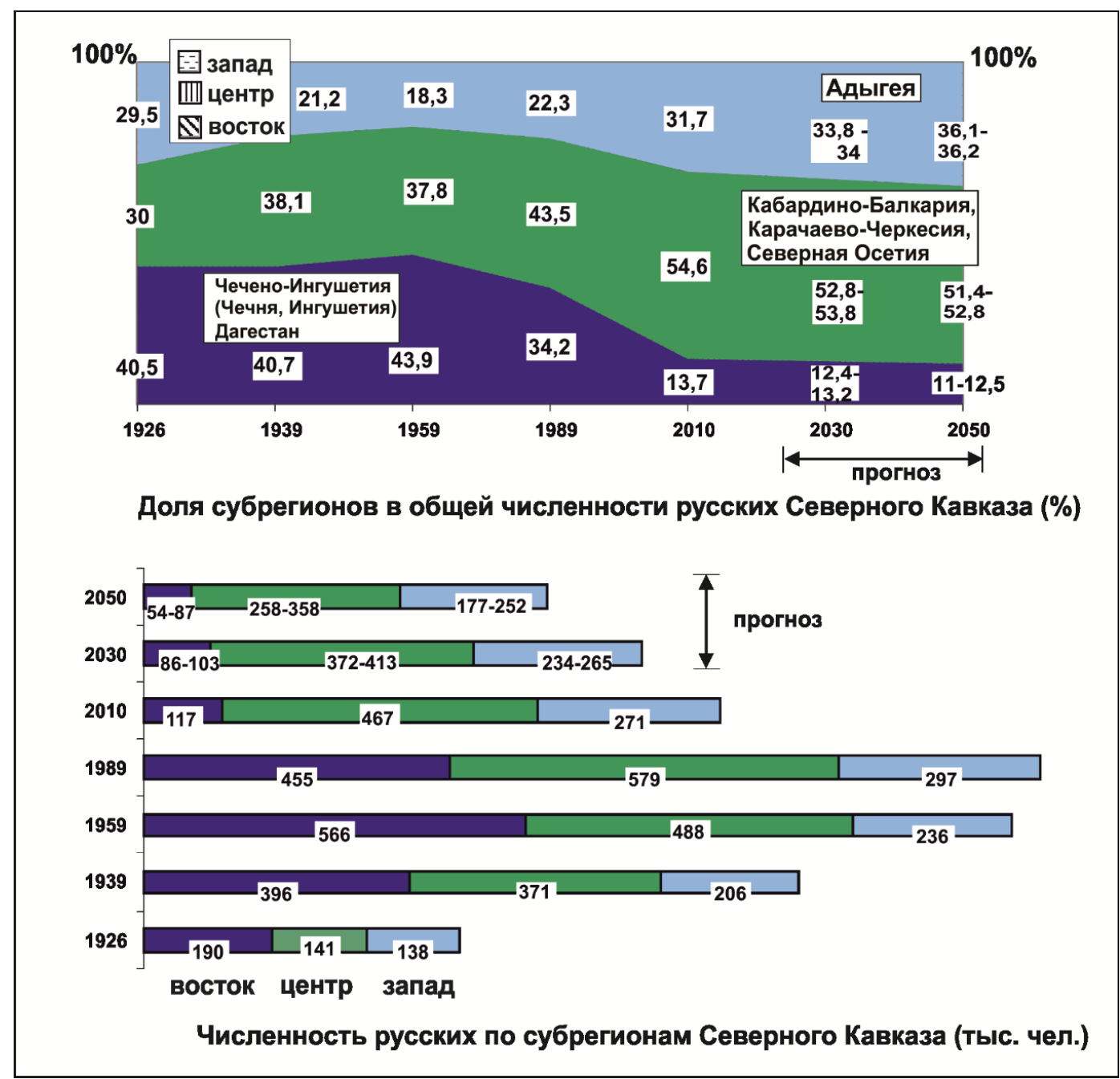

Рисунок 12. Русское население по субрегионам Северного Кавказа, 1926-2050 гг. , \%, тыс. человек

Однако следует понимать, что горизонт нашего исследования ограничен серединой XXI века. До этого времени вероятность резкого сокращения численности русских мала. Но сама устойчивость естественной убыли и миграционного оттока в сумме с негативными сдвигами половозрастной структуры существенно повышает вероятность сценария демографического коллапса республиканских русских во второй половине столетия. И здесь не важно, о третьей или четвертой его четверти идет речь. Раньше на 20-30 лет или позже, но медианный возраст русского населения Северного Кавказа может превысить 50 летний рубеж. С этого времени его демографическое сжатие начнет приобретать необратимый и самоускоряющийся характер.

\section{ЛИТЕРАТУРА}

Атаев A.B. (2013). Статус и перспективы русского населения на Северном Кавказе. URL: https://riss.ru/smi/3836/ (дата обращения 14.02.2017).

Белозеров В.С. (2001). Русские на Северном Кавказе: эволюция расселения // Русские на Северном Кавказе: вызовы ХХІ века. Ростов-на-Дону: ИППК РГУ и ИСПИ РАН: 5870. 
Дагестан-2005: Социально-экономическое положение (2006). Махачкала: Комитет по статистке РД. 244 с.

Денисова Г.С., В.П. Уланов (2003). Русские на Северном Кавказе: анализ трансформации социокультурного статуса. Ростов-на-Дону: Изд-во РГПУ. 352 с.

Дзадзиев А.Б. (2007). Современная этнографическая ситуация // Бюллетень сети этнологического мониторинга и раннего предупреждения конфликтов. 74 (июльавгуст): 56-59.

Дзадзиев А.Б. (2008). Русское население республик Северного Кавказа: современные миграционные установки // Северный Кавказ в национальной стратегии России. М.: Росинформагротех: 129-148.

Кабузан В.М. (1996). Население Северного Кавказа в XIX-XX веках. СПб: Блиц. 224 с.

Северный Кавказ: русский фактор (2010). Экспертный доклад. URL: http://www.rusobr.ru/library/6438 (дата обращения: 18.02.2017). 


\title{
RUSSIANS IN THE REPUBLICS OF THE NORTH CAUCASUS: FRONTIERS OF GEO-DEMOGRAPHIC RETREAT (THE FIRST HALF OF THE 21St CENTURY)
}

\section{SERGEI SUSHCHIY}

\begin{abstract}
The article analyzes the geo-demographic dynamics of the Russian population of the republics of the North Caucasus in the post-Soviet period, recording the pace of its reduction in each republic and revealing the central role of migration in this depopulation process. Currently, the Russian population of the North Caucasus has returned to the level of the mid-1930s. The Republic of Chechnya and Ingushetia are now almost completely devoid of Russians, and Dagestan has lost a significant part of its Russian population. Demographic losses in other republics of the region have not been as great. However, a rapidly decreasing number of Russians has become a steady trend of the entire North Caucasus. In order to determine the corridor of most likely dynamics of the Russian population in the region for the period until 2050, a series of calculations was carried out. It was established that by 2030 the number of Russians in the North Caucasus will be reduced to 690-780 thousand people, and by mid-century - to 490-700 thousand.
\end{abstract}

Another significant threat will be the deterioration of the age structure of the local Russian population, which could lead to its demographic "collapse" in the 2060-2070-ies.

Key words: North Caucasus, Russian population, the demographic dynamics and settlement, migration, assimilation processes

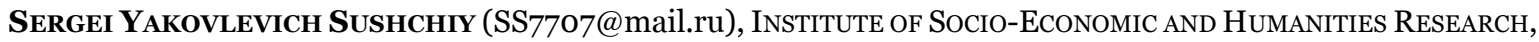
SSC RAS, RUSSIA.

THE WORK IS IMPLEMENTED WITHIN THE FRAMEWORK OF THE PROJECT "PROBLEMS OF DEMOGRAPHIC AND SOCIAL AND ECONOMIC DEVELOPMENT OF THE SOUTHERN MACROREGION (O260-2014-0004)" PROGRAM OF THE BASIC RESEARCHES OF THE PRESIDIUM OF THE RAS.

DATE RECEIVED : APRIL 2017.

\section{REFERENCES}

Ataev A.V. (2013). Status i perspektivy russkogo naseleniya na Severnom Kavkaze [Status and the prospects of the Russian population in the North Caucasus]. URL:

https://riss.ru/smi/3863/ (accessed: 14.02.2017).

Belozerov V. S. (2001). Russkie na Severnom Kavkaze: evolyutsiya rasseleniya [Russians on the North Caucasus: the evolution of settlement] // Russkie na Severnom Kavkaze: vyzovy XXI veka [Russians on the North Caucasus: challenges of the XXI century]. Rostov-na-Donu: IPPK RGU i ISPI RAN: 58-70.

Dagestan-2005: Sotsial'no-ekonomicheskoe polozhenie [Dagestan-2005: Socio-economic status] (2006). Makhachkala: Komitet po statistke RD. 244 p.

Denisova G.S., V.P. Ulanov (2003). Russkie na Severnom Kavkaze: analiz transformatsii sotsiokul'turnogo statusa [Russians on the North Caucasus: analysis of transformation of socio-cultural status]. Rostov-na-Donu: Izdatel'stvo RGPU. 352 p.

Dzadziev A. B. (2007). Sovremennaya etnograficheskaya situatsiya [Modern ethnographic situation] // Byulleten' seti etnologicheskogo monitoringa i rannego preduprezhdeniya konfliktov [Bulletin of the network of ethnological monitoring and early conflict prevention]. 74 (iyul'-avgust) [74, July-August]. Moscow: 56-59. 
Dzadziev A.B. (2008). Russkoe naselenie respublik Severnogo Kavkaza: sovremennye migratsionnye ustanovki [Russian population of the North Caucasus: current migration installation] // Severniy Kavkaz v natsional'noy strategii Rossii [Northern Caucasus in the national strategy of Russia]. Moscow: Rosinformagrotekh: 129-148.

Kabuzan V.M. (1996). Naselenie Severnogo Kavkaza v XIX-XX vekakh [The population of the North Caucasus in the 19-20th centuries]. St. Petersburg: Blits. 224 p.

Severnyy Kavkaz: russkiy faktor [The North Caucasus: Russian factor] (2010). Ekspertnyy doklad [Expert report]. URL: http://www.rus-obr.ru/library/6438 (accessed: 18.02.2017). 